\title{
Nursery origin of yellowfin tuna in the Hawaiian Islands
}

\author{
R. J. David Wells ${ }^{1, *}$, Jay R. Rooker ${ }^{1}$, David G. Itano ${ }^{2}$ \\ ${ }^{1}$ Department of Marine Biology, Texas A\&M University at Galveston, 1001 Texas Clipper Road, Galveston, Texas 77553, USA \\ ${ }^{2}$ Pelagic Fisheries Research Program, University of Hawai'i, 1000 Pope Rd, MSB 312, Honolulu, Hawaii 96822, USA
}

\begin{abstract}
Stable isotopes of carbon $\left(\delta^{13} \mathrm{C}\right)$ and oxygen $\left(\delta^{18} \mathrm{O}\right)$ in otolith cores (first 2 mo of age) of young-of-the-year (YOY) yellowfin tuna Thunnus albacares were used as natural tracers to predict the nursery origin of sub-adults (age-1) collected from the Hawaiian Islands. YOY fish were first collected from nurseries throughout the western and central Pacific Ocean (WCPO) to determine whether $\delta^{13} \mathrm{C}$ and $\delta^{18} \mathrm{O}$ values of otolith cores $\left(\delta^{13} \mathrm{C}_{\text {otolith }}\right.$ and $\left.\delta^{18} \mathrm{O}_{\text {otolith }}\right)$ were sufficiently different to discriminate individuals from different nurseries used during the YOY period. Nurseries examined included both nearshore Hawaiian Islands and offshore Hawaiian Islands (Cross Seamount), and 4 locations in the equatorial Pacific Ocean: Line Islands, Marshall Islands, Solomon Islands, and Philippines. Significant differences existed in $\delta^{13} \mathrm{C}_{\text {otolith }}$ and $\delta^{18} \mathrm{O}_{\text {otolith }}$ among YOY yellowfin tuna from different nurseries for each year of the 2 yr study period (2008-2009). Individuals from the nearshore Hawaiian Islands were most enriched in $\delta^{18} \mathrm{O}_{\text {otolith, }}$ while samples obtained from the Philippines were most depleted in both $\delta^{13} \mathrm{C}_{\text {otolith }}$ and $\delta^{18} \mathrm{O}_{\text {otolith }}$ relative to other regions. Inter-annual variability in otolith core chemistry was minor and only observed for individuals collected from the Philippines. Overall classification success from quadratic discriminant function analysis of YOY yellowfin tuna to their respective nursery of collection was 63 and $87 \%$ for 2008 and 2009, respectively. Mixed-stock analysis indicated $91 \%$ of the sub-adult yellowfin tuna collected from the nearshore Hawaiian Islands originated from this same nursery. In addition, sub-adults from the offshore location within the Hawaiian Islands appear to originate from the nearshore Hawaiian Islands, highlighting the importance of local production and retention of yellowfin tuna to the standing stock and domestic fisheries of Hawaii.
\end{abstract}

KEY WORDS: Stable carbon and oxygen isotopes - Yellowfin tuna $\cdot$ Nursery origin - Otolith chemistry $\cdot$ Hawaiian Islands $\cdot$ Stock structure

\section{INTRODUCTION}

Tuna stocks of the western and central Pacific Ocean (WCPO) represent $84 \%$ of the total Pacific Ocean catch and $60 \%$ of the global tuna catch (Williams \& Terawasi 2011). Exploitation rates on WCPO tuna stocks have increased steadily over the past 3 decades with mortality rates approaching maximum sustainable yield (MSY) levels. A species of particular importance in the WCPO is yellowfin tuna Thunnus albacares, which yields approximately
$400000 \mathrm{t} \mathrm{yr}^{-1}$. Fishing mortality for juvenile and adult yellowfin tuna is estimated to have increased continuously since the beginning of industrial fishing in the region with the current stock assessment predicting a steady decline in total and spawning stock biomass (Langley et al. 2011). The variable movement parameters and recruitment variability of yellowfin tuna combined with diverse gear types and exploitation rates throughout the WCPO makes regional and international management strategies complicated. Consequently, a more refined understanding of the 
movement and stock structure of yellowfin tuna within the WCPO is needed to effectively guide the management of this species.

Several complementary approaches have been used to address the movement and stock structure of yellowfin tuna in the Pacific Ocean, including molecular genetics, morphology, and tagging (conventional, electronic). Genotypic and phenotypic data of yellowfin tuna indicate limited gene flow between WCPO and eastern Pacific Ocean regions (Schaefer 1992, Ward et al. 1997) and genetic differentiation was observed between samples north and south of the equator in the eastern Pacific (Díaz-Jaimes \& Uribe-Alcocer 2006). Tagging data also suggest that regional movement in the Pacific Ocean is limited, signifying that some degree of stock heterogeneity occurs within this basin (Itano \& Holland 2000, Schaefer et al. 2007).

In the Hawaiian Islands, local spawning of yellowfin tuna has been documented but the degree of local recruitment remains unknown (Itano 2000). Tagging studies in waters surrounding the main Hawaiian Islands generally support the premise of retentive behaviours of yellowfin tuna and long-distance $(>1000 \mathrm{~km}$ ) movements are thought to be rare (Itano \& Holland 2000). Hampton \& Fournier (2001) developed a length-based and age-structured model for yellowfin tuna throughout the WCPO that assumed a large fraction of the yellowfin tuna harvested in the Hawaii-based fisheries originated from equatorial regions. Thus, the origin of recruits in the Hawaiian Islands remains uncertain and this information is critical to reduce uncertainty in population models and develop spatially explicit management strategies.

Recent studies using chemical signatures in otoliths have shown that these natural markers are valuable for evaluating the origin and movement of tunas in the Pacific Ocean (Rooker et al. 2001, Wang et al. 2009, Shiao et al. 2010). The principal assumption underlying this approach is that the otolith accretes material as the fish grows and the chemical composition of the otolith is related to the physicochemical conditions of the water mass inhabited (Rooker et al. 2001). Therefore, material deposited in the otolith during the first weeks to months of life may serve as a natural tag of an individual's place of origin. Previous studies have demonstrated that stable isotopes of carbon $\left(\delta^{13} \mathrm{C}\right)$ and oxygen $\left(\delta^{18} \mathrm{O}\right)$ in otolith cores (hereafter $\delta^{13} \mathrm{C}_{\text {otolith }}$ and $\delta^{18} \mathrm{O}_{\text {otolith }}$ ) can be used to determine the origin of tropical and temperate tunas (Gunn \& Ward 1994, Rooker et al. 2008a,b, Schloesser et al. 2010), and thus may prove useful for determining contribution rates of yellowfin tuna recruits from different nurseries throughout the WCPO.

Here, we investigate the nursery origin of subadult (age-1) yellowfin tuna from 2 nurseries of the Hawaiian Islands using $\delta^{13} \mathrm{C}_{\text {otolith }}$ and $\delta^{18} \mathrm{O}_{\text {otolith }}$. These nurseries are referred to as 'nearshore' referring to multiple sampling areas within $30 \mathrm{~km}$ of the main Hawaiian Islands and 'offshore' referring to samples collected on the Cross Seamount, an isolated bathymetric feature approximately $300 \mathrm{~km}$ south of Oahu. We were specifically interested in determining whether sub-adult yellowfin tuna collected in nearshore and offshore nurseries of the Hawaiian Islands were locally produced (residents) or had immigrated from distant areas (transients) of the equatorial Pacific Ocean. We first assessed spatial and temporal variability in $\delta^{13} \mathrm{C}_{\text {otolith }}$ and $\delta^{18} \mathrm{O}_{\text {otolith }}$ in the otolith cores of young-of-the-year (YOY, age-0) yellowfin tuna to determine whether individuals from different nurseries of the WCPO could be discriminated and these data were then used to develop baseline signatures for mixed-stock analysis of subadult yellowfin tuna. Next, we targeted sub-adult yellowfin tuna that were recruited into the nearshore and offshore Hawaiian Island fisheries and predicted their origin by examining $\delta^{13} \mathrm{C}_{\text {otolith }}$ and $\delta^{18} \mathrm{O}_{\text {otolith }}$ in the otolith cores (equal to a restricted portion of the YOY period) of these individuals.

\section{MATERIALS AND METHODS}

YOY yellowfin tuna were collected from 6 nurseries throughout the WCPO: (1) nearshore Hawaiian Islands (ca. $\leq 30 \mathrm{~km}$ from land), (2) offshore Hawaiian Islands (Cross Seamount, $300 \mathrm{~km}$ southwest of the Hawaiian Islands), (3) Line Islands of Kiribati, (4) Marshall Islands, (5) Solomon Islands, and (6) Philippines (Fig. 1). Yellowfin tuna were collected over a 2 yr period (late 2007 to early 2008 and late 2008 to early 2009, hereafter 2008 and 2009, respectively) through either hook-and-line or purse seine techniques. Within each nursery, sub-samples from multiple collection dates and locations were taken to ensure that baseline $\delta^{13} \mathrm{C}_{\text {otolith }}$ and $\delta^{18} \mathrm{O}_{\text {otolith }}$ values were representative of each nursery. For example, YOY yellowfin tuna collected from the nearshore Hawaiian Islands were obtained from multiple collection dates and islands (Kauai, Maui, and Oahu). For purposes of this study, we define nurseries as primary regions used by YOY yellowfin tuna in the WCPO and are therefore considered as important habitat during the first year of life, while not implying 


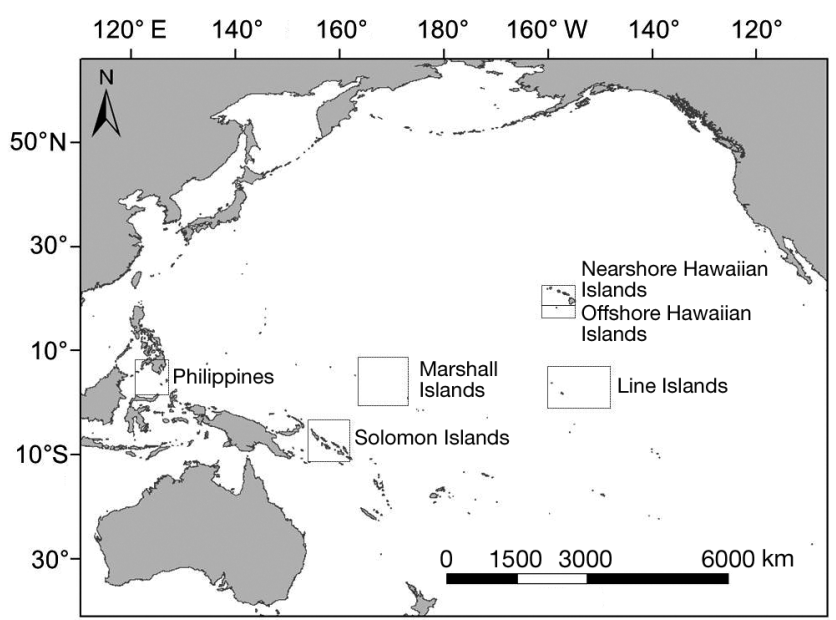

Fig. 1. Location of the 6 nursery areas used as sample sites in the western and central Pacific Ocean (WCPO). Nurseries include: nearshore Hawaiian Islands (ca. $\leq 30 \mathrm{~km}$ from land), offshore Hawaiian Islands (Cross Seamount, $300 \mathrm{~km}$ south of Oahu), Line Islands, Marshall Islands, Solomon Islands, and Philippines

spawning location since yellowfin tuna are pelagic broadcast spawners.

Sub-adult yellowfin tuna were collected in 2009 from the nearshore Hawaiian Islands and in 2010 from the offshore Hawaiian Islands to investigate nursery-specific contribution rates (Table 1). Similar to YOY fish, sub-adults were collected over a range of dates from nearshore areas of Kauai, Maui, Oahu and the island of Hawaii. Based on previous otolithbased ageing studies in the Pacific Ocean (Uchiyama \& Struhsaker 1981, Wild 1986, Lehodey \& Leroy 1999), yellowfin tuna ranging in size from 21 to $59 \mathrm{~cm}$ fork length (FL) and 60 to $100 \mathrm{~cm}$ FL were classified as YOY (age-0) and sub-adults (age-1), respectively.

Sagittal otoliths were extracted from both fresh and frozen specimens, cleaned of biological residue, and stored dry in plastic vials. In the laboratory, whole otoliths were first soaked in doubly deionized water $\left(\mathrm{DDIH}_{2} \mathrm{O}\right)$, moved to a $3 \%$ hydrogen peroxide solution for $5 \mathrm{~min}$ to eliminate any remaining biological material, and then transferred into a new $\mathrm{DDIH}_{2} \mathrm{O}$ bath for $5 \mathrm{~min}$ to remove surface residue. One sagittal otolith from each yellowfin tuna was embedded in Struers epoxy resin (EpoFix) and sectioned using a low speed ISOMET saw to obtain $1.5 \mathrm{~mm}$ transverse sections that included the core. Following attachment to a sample plate, the portion of the otolith core corresponding to approximately the first 2 mo of life was milled from the otolith section using a New Wave Research MicroMill system. A 2-vector drill path based upon otolith measurements of 10 small individual yellowfin tuna (mean \pm SE fish length: $22.4 \pm 0.13 \mathrm{~cm} \mathrm{FL,}$ range: 21.8 to $23.0 \mathrm{~cm}$ FL) was created and used as the standard template to isolate core material ( 0 to $2 \mathrm{mo}$ ) for YOY and sub-adult yellowfin tuna (Fig. 2). The pre-programmed drill path was made using a $500 \mu \mathrm{m}$ diameter drill bit and 14 passes each at a depth of $55 \mu \mathrm{m}(770 \mu \mathrm{m}$ total) were used to obtain core material from the otolith. Shiao et al. (2009) suggested that a small amount of calcium carbonate material on the outer edge may be deposited around the area surrounding the core during sub-adult and adult stages for southern bluefin tuna Thunnus maccoyii. Consequently, a small amount of outer edge material may have been incorporated into the powdered core material, but the amount of material was likely so

Table 1. Thunnus albacares. Summary statistics of young-of-the-year (YOY, age-0) and sub-adult (age-1) yellowfin tuna collected throughout western and central Pacific Ocean (WCPO) study areas. Mean ( $\pm 1 \mathrm{SE})$ size and size range are fork lengths (FL), and collection dates given as mm/dd/yyyy

\begin{tabular}{|lccccc}
\hline Study area & Year & $\mathrm{n}$ & Mean size (cm FL) & Size range (cm FL) & Collection dates \\
\hline YOY & & & & & $10 / 1 / 2007-1 / 10 / 2008$ \\
Nearshore Hawaii & 2008 & 30 & $37.5(0.98)$ & $27.9-50.0$ & $1 / 26 / 2009-1 / 29 / 2009$ \\
Nearshore Hawaii & 2009 & 20 & $35.3(0.75)$ & $29.0-41.0$ & $2 / 22 / 2008-3 / 16 / 2008$ \\
Offshore Hawaii & 2008 & 25 & $54.3(0.78)$ & $44.0-59.0$ & $4 / 20 / 2008-5 / 28 / 2008$ \\
Line Islands & 2008 & 25 & $53.3(0.75)$ & $48.0-59.0$ & $5 / 23 / 2009-10 / 12 / 2009$ \\
Line Islands & 2009 & 13 & $46.9(1.18)$ & $39.0-54.0$ & $1 / 1 / 2008-3 / 3 / 2008$ \\
Marshall Islands & 2008 & 25 & $30.7(0.51)$ & $27.0-35.0$ & $4 / 12 / 2009-4 / 18 / 2009$ \\
Marshall Islands & 2009 & 16 & $53.9(0.74)$ & $37.0-58.0$ & $3 / 2 / 2008-3 / 14 / 2008$ \\
Solomon Islands & 2008 & 25 & $35.1(0.37)$ & $21.8-33.0$ & $12 / 22 / 2007-1 / 12 / 2008$ \\
Philippines & 2008 & 25 & $26.0(0.73)$ & $24.8-37.0$ & $12 / 22 / 2008-1 / 3 / 2009$ \\
Philippines & 2009 & 19 & $30.8(1.03)$ & & \\
Sub-adult & & & & $60.0-97.0$ & $1 / 26 / 2009-3 / 16 / 2009$ \\
Nearshore Hawaii & 2009 & 100 & $69.4(0.81)$ & $61.0-98.0$ & $4 / 11 / 2010-6 / 12 / 2010$ \\
Offshore Hawaii & 2010 & 25 & $79.5(1.60)$ & & \\
\hline
\end{tabular}




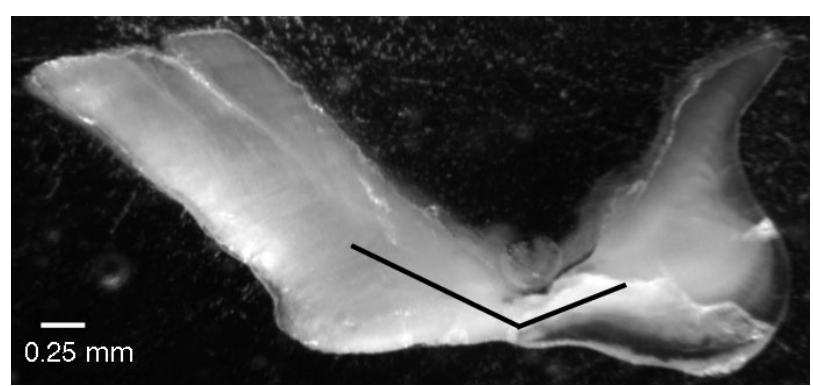

Fig. 2. Thunnus albacares. Transverse cross section of a subadult yellowfin tuna sagittal otolith showing the primary drill path used on all samples to core out the inner region of the otolith corresponding to the first months of life to predict nursery origin

minimal that it would not affect the results for the life stages investigated in this study. Powdered core material was transferred to silver capsules and later analyzed for $\delta^{13} \mathrm{C}_{\text {otolith }}$ and $\delta^{18} \mathrm{O}_{\text {otolith }}$ on an automated carbonate preparation device (KIEL-III) coupled to a gas-ratio mass spectrometer (Finnigan MAT 252) maintained at the University of Arizona's Environmental Isotope Laboratory. The isotope ratio measurement was calibrated based on repeated measurements of National Bureau of Standards (NBS), NBS-19 and NBS-18, with 6 standards ran for every 40 samples and precision was $\pm 0.11 \%$ (SD) for $\delta^{18} \mathrm{O}$ and $\pm 0.08 \%$ (SD) for $\delta^{13} \mathrm{C}$. Stable $\delta^{13} \mathrm{C}$ and $\delta^{18} \mathrm{O}$ isotopes are reported relative to the PeeDee belemnite (PDB) scale after comparison to an in-house laboratory standard calibrated to PDB.

Multivariate analysis of variance (MANOVA) was used to test for differences in $\delta^{13} \mathrm{C}_{\text {otolith }}$ and $\delta^{18} \mathrm{O}_{\text {otolith }}$ of YOY yellowfin tuna among nurseries sampled; Pillai's trace statistic was used to test for significance. Univariate tests for both $\delta^{13} \mathrm{C}_{\text {otolith }}$ and $\delta^{18} \mathrm{O}_{\text {otolith }}$ were also performed using analysis of variance (ANOVA) and a posteriori differences among means were detected with Tukey's honestly significant difference (HSD) test. The variance-covariance matrix of predictor variables was different among samples so quadratic discriminant function analysis (QDFA) was used to evaluate the classification accuracy of individual YOY yellowfin tuna to nurseries based on the jackknife reclassification (Rooker et al. 2008a). Quadratic discriminant function analysis does not have the homogeneity of covariance matrices assumption and is robust to moderate deviations from normality (McGarigal et al. 2000). Nursery-specific contribution estimates of yellowfin recruits to nearshore and offshore Hawaii were obtained using the maximum likelihood mixed-stock analysis program HISEA developed by Millar (1990). The baseline data set used for mixed-stock analysis was $\delta^{13} \mathrm{C}_{\text {otolith }}$ and $\delta^{18} \mathrm{O}_{\text {otolith }}$ of YOY samples collected from the 6 nurseries in 2008. Otolith cores of sub-adult samples collected from the nearshore and offshore Hawaiian Island nurseries (collected in 2009 and 2010, respectively) were used to estimate the origin of these recruits in the bootstrap mode of HISEA with 1000 simulations, which provided non-parametric estimates of the reliability of predicted contributions from the different nurseries. All other statistical analyses were performed using SYSTAT 10.0 (SYSTAT Software) and significance for all tests was determined at the alpha level of 0.05 .

\section{RESULTS}

$\delta^{13} \mathrm{C}_{\text {otolith }}$ and $\delta^{18} \mathrm{O}_{\text {otolith }}$ of YOY yellowfin tuna significantly differed among the nurseries sampled and showed similar spatial variation in both years of the study (MANOVA, $\mathrm{p}<0.01$ ) (Fig. 3). $\delta^{13} \mathrm{C}_{\text {otolith }}$ of YOY fish was most enriched for individuals collected from the Marshall Islands (mean \pm SE, 2008: $-9.29 \pm 0.09$; 2009: $-9.32 \pm 0.10 ; \mathrm{p}<0.01)$, with mean values 0.37 to $1.27 \%$ (2008) and 0.42 to $0.55 \%$ (2009) that were significantly more enriched relative to other nurseries (Tukey HSD, $\mathrm{p}<0.05) . \delta^{13} \mathrm{C}_{\text {otolith }}$ values of YOY fish from the Philippines were the most depleted (2008: $-10.56 \pm 0.08 ; 2009$ : $-9.87 \pm 0.09 ; \mathrm{p}<0.01$ ), while values for the other 4 nurseries were relatively similar with mean values within $0.08 \%$ of each other. $\delta^{18} \mathrm{O}_{\text {otolith }}$ of YOY fish also varied among nurseries but spatial variation was different from $\delta^{13} C_{\text {otolith }}$. The most enriched $\delta^{18} \mathrm{O}_{\text {otolith }}$ values were observed for YOY yellowfin tuna from the nearshore Hawaiian Islands (2008: $-1.77 \pm 0.03 ; 2009:-1.69 \pm 0.03)$, with mean values significantly enriched relative to other nurseries (Tukey HSD, p < 0.05 ) by 0.33 to $0.88 \%$ and 0.67 to $1.13 \%$ in 2008 and 2009 , respectively. $\delta^{18} \mathrm{O}_{\text {otolith }}$ values of YOY decreased east to west and were significantly depleted in samples obtained from the Philippines in both years $(2008:-2.65 \pm 0.05 ; 2009$ $-2.82 \pm 0.05)$ with the exception of similar $\delta^{18} \mathrm{O}_{\text {otolith }}$ between YOY fish from the Philippines and Solomon Islands in $2008(\mathrm{p}=0.867)$.

Inter-annual comparisons of $\delta^{13} \mathrm{C}_{\text {otolith }}$ and $\delta^{18} \mathrm{O}_{\text {otolith }}$ of YOY yellowfin tuna were possible for 4 nurseries; missing year classes for offshore Hawaiian Islands and Solomon Islands precluded assessments in these nurseries. Differences in $\delta^{13} \mathrm{C}_{\text {otolith }}$ and $\delta^{18} \mathrm{O}_{\text {otolith }}$ of YOY from 2008 and 2009 were only detected in the Philippines. YOY yellowfin tuna in the Philippines in 2008 had significantly depleted $\delta^{13} \mathrm{C}_{\text {otolith }}$ and signifi- 


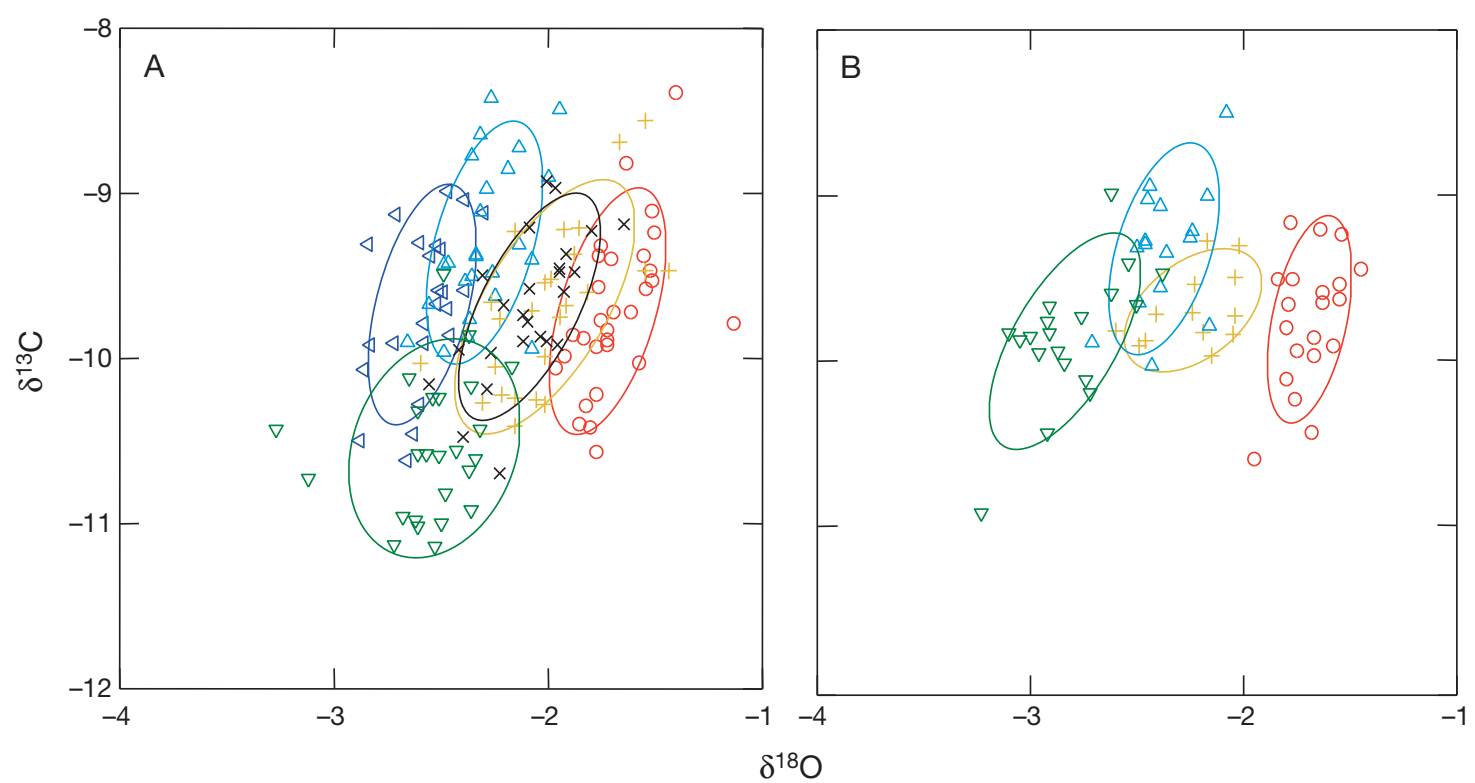

Fig. 3. Thunnus albacares. Otolith core carbon $\left(\delta^{13} \mathrm{C}_{\text {otolith }}\right)$ and oxygen $\left(\delta^{18} \mathrm{O}_{\text {otolith }}\right)$ stable isotopes of young-of-the-year $(Y O Y$, age-0) yellowfin tuna collected among nurseries in (A) 2008 and (B) 2009. Confidence ellipses represent 1 SD around the mean. Nurseries include $(O)$ nearshore Hawaiian Islands, $(X)$ offshore Hawaiian Islands, $(+)$ Line Islands, $(\Delta)$ Marshall Islands,

$(\triangleleft)$ Solomon Islands, and $(\nabla)$ Philippines

cantly enriched $\delta^{18} \mathrm{O}_{\text {otolith }}$ relative to 2009 by $0.69 \%$ $(\mathrm{p}<0.01)$ and $0.17 \%$ o $(\mathrm{p}=0.02)$, respectively (Fig. 3). In contrast, no significant difference in $\delta^{13} \mathrm{C}_{\text {otolith }}$ or $\delta^{18} \mathrm{O}_{\text {otolith }}$ existed in samples collected between 2008 and 2009 in the nearshore Hawaiian Islands $\left(\delta^{13} \mathrm{C}\right.$ : $\left.\mathrm{p}=0.73 ; \delta^{18} \mathrm{O}: \mathrm{p}=0.09\right)$, Line Islands $\left(\delta^{13} \mathrm{C}: \mathrm{p}=0.94\right.$; $\left.\delta^{18} \mathrm{O}: \mathrm{p}=0.07\right)$, and Marshall Islands $\left(\delta^{13} \mathrm{C}: \mathrm{p}=0.83\right.$; $\delta^{18} \mathrm{O}: \mathrm{p}=0.95$ ).

Discrimination of YOY yellowfin tuna among the nurseries surveyed was relatively high using $\delta^{13} \mathrm{C}_{\text {otolith }}$ and $\delta^{18} \mathrm{O}_{\text {otolith }}$ with overall classification success of 63 and $87 \%$ for 2008 and 2009, respectively. Expected classification success based on random assignments for each year was 17 (2008 based on 6 nurseries) and $25 \%$ (2009 based on 4 nurseries). In 2008, classification success of YOY fish was highest for the Philippines (84\%) followed by nearshore Hawaiian Islands (80\%). In 2009, classification success of YOY fish from the nearshore Hawaiian Islands was $100 \%$ followed by Line Islands at $85 \%$. Our ability to discriminate individuals from other nurseries ranged from 20 (Line Islands in 2008 ) to $81 \%$ (Marshall Islands in 2009) (Table 2). Using only $\delta^{13} \mathrm{C}_{\text {otolith }}$ or $\delta^{18} \mathrm{O}_{\text {otolith }}$ in QDFA models resulted in a reduction in overall classification success $\left(\delta^{13} \mathrm{C}_{\mathrm{o}}\right.$ tolith only: $33 \%$ in $2008,40 \%$ in $2009 ; \delta^{18} \mathrm{O}_{\text {otolith }}$ only: $47 \%$ in $2008,79 \%$ in 2009), suggesting that both $\delta^{13} \mathrm{C}_{\text {otolith }}$ and $\delta^{18} \mathrm{O}_{\text {otolith }}$ markers were useful for assigning the origin of YOY yellowfin tuna.

$\delta^{13} \mathrm{C}_{\text {otolith }}$ and $\delta^{18} \mathrm{O}_{\text {otolith }}$ of sub-adult yellowfin tuna $(\mathrm{n}=100)$ collected from 4 locations in the nearshore Hawaiian Islands (Hawaii, Kauai, Maui, and Oahu)

Table 2. Thunnus albacares. Mean $( \pm 1 \mathrm{SE})$ otolith carbon $\left(\delta^{13} \mathrm{C}\right)$ and oxygen $\left(\delta^{18} \mathrm{O}\right)$ stable isotope values of young-of-the-year (YOY, age-0) and sub-adult (age-1) yellowfin tuna collected among western and central Pacific Ocean (WCPO) nursery areas. Classification success (\%) from quadratic discriminant function analysis is also included for each nursery area by year

\begin{tabular}{|lcccc|}
\hline Nursery area & Year & $\delta^{13} \mathrm{C}$ & $\delta^{18} \mathrm{O}$ & $\begin{array}{c}\text { Classification } \\
\text { success (\%) }\end{array}$ \\
\hline YOY & & & & \\
Nearshore Hawaii & 2008 & $-9.70(0.09)$ & $-1.77(0.03)$ & 80 \\
& 2009 & $-9.74(0.09)$ & $-1.69(0.03)$ & 100 \\
Offshore Hawaii & 2008 & $-9.68(0.09)$ & $-2.16(0.04)$ & 52 \\
Line Islands & 2008 & $-9.68(0.10)$ & $-2.10(0.05)$ & 20 \\
& 2009 & $-9.69(0.06)$ & $-2.24(0.05)$ & 85 \\
Marshall Islands & 2008 & $-9.29(0.09)$ & $-2.37(0.03)$ & 72 \\
& 2009 & $-9.32(0.10)$ & $-2.37(0.04)$ & 81 \\
Solomon Islands & 2008 & $-9.66(0.09)$ & $-2.64(0.03)$ & 68 \\
Philippines & 2008 & $-10.56(0.08)$ & $-2.65(0.05)$ & 84 \\
& 2009 & $-9.87(0.09)$ & $-2.82(0.05)$ & 79 \\
Sub-adult & & & & \\
Nearshore Hawaii & 2009 & $-9.41(0.05)$ & $-1.73(0.02)$ & \\
Offshore Hawaii & 2010 & $-9.93(0.07)$ & $-1.87(0.04)$ & \\
\hline
\end{tabular}


were compared to the YOY baseline samples collected during the previous year (age-class matching) to predict the origin of these fish. $\delta^{13} \mathrm{C}_{\text {otolith }}(p=0.812)$ and $\delta^{18} \mathrm{O}_{\text {otolith }}(\mathrm{p}=0.900)$ did not significantly differ among the 4 locations and therefore samples from all 4 islands were pooled for mixed-stock analysis. $\delta^{13} \mathrm{C}_{\text {otolith }}$ of sub-adult yellowfin tuna ranged from -8.08 to $-10.59 \%$ (Fig. 4), closely overlapping the $\delta^{13} \mathrm{C}_{\text {otolith }}$ of YOY fish obtained from all nurseries except the Philippines. $\delta^{18} \mathrm{O}_{\text {otolith }}$ of sub-adults from the nearshore Hawaiian Islands ranged from -1.14 to $-2.26 \%$ (mean: $-1.73 \%$ ) and was similar to that of YOY fish from nearshore Hawaiian Islands (range: -1.22 to $-2.05 \%$; mean: $-1.77 \%$ ) (Fig. 4). Further, $\delta^{18} \mathrm{O}_{\text {otolith }}$ of sub-adults was enriched by 0.37 to $0.92 \%$ relative to mean $\delta^{18} \mathrm{O}_{\text {otolith }}$ of samples from the other 5 nurseries used for baseline contribution estimates. Results of mixed-stock analysis indicated that $90.6 \pm$ $8.6 \%$ (mean $\pm \mathrm{SD}$ ) of sub-adults in our nearshore Hawaiian Islands sample originated from this nursery (Fig. 5), suggestive of local recruitment. Mixedstock analysis also showed minor contributions from the 2 closest nurseries to the south of the nearshore Hawaiian Islands: Line Islands $(7.3 \pm 9.0 \%)$ and offshore Hawaiian Islands $(2.1 \pm 4.5 \%)$, with no contribution from other nurseries.

Nursery origin of sub-adult yellowfin tuna was also predicted for samples collected in the offshore Hawaiian Islands (i.e. Cross Seamount) using $\delta^{13} \mathrm{C}_{\text {otolith }}$ and $\delta^{18} \mathrm{O}_{\text {otolith }}(\mathrm{n}=25) \cdot \delta^{13} \mathrm{C}_{\text {otolith }}$ of sub-adult yellowfin tuna from this nursery ranged from -9.43 to $-10.91 \%$, with a mean of $-9.93 \%$ (Fig. 4). For $\delta^{18} \mathrm{O}_{\text {otolith, values }}$ of sub-adults ranged from -1.43 to $-2.14 \%$ (mean: $-1.87 \%$ ) and differed markedly from YOY collected in the offshore Hawaiian Islands (Fig. 4). Mixed-stock analysis indicated that local production in the offshore Hawaiian Islands was negligible $(0.7 \pm 3.4 \%$, mean $\pm \mathrm{SD}$ ) and recruits to this nursery were derived primarily from the nearshore Hawaiian Islands (89.9 $\pm 12.5 \%$ ), with the remaining contribution from the Line Islands (9.4 $\pm 12.5 \%$ ) (Fig. 5).

\section{DISCUSSION}

$\delta^{13} \mathrm{C}_{\text {otolith }}$ of YOY yellowfin tuna was similar among 4 of the 6 nurseries examined (nearshore Hawaiian Islands, offshore Hawaiian Islands, Line Islands, Solomon Islands), averaging less than $0.1 \%$, while $\delta^{13} \mathrm{C}_{\text {otolith }}$ of yellowfin tuna from the Philippines was depleted relative to other nurseries. A positive relationship between $\delta^{13} \mathrm{C}_{\text {otolith }}$ and salinity $(\sim 0.1 \%$ increase in $\delta^{13} \mathrm{C}_{\text {otolith }}$ per 1 psu increase) combined with an inverse relationship between $\delta^{13} \mathrm{C}_{\text {otolith }}$ and sea surface temperature $(<0.1$ to $0.25 \%$ decrease in $\delta^{13} \mathrm{C}_{\text {otolith }}$ per $1^{\circ} \mathrm{C}$ increase) has been reported in other studies (Elsdon \& Gillanders 2002, Kerr et al. 2007). Consequently, the low salinity (mean salinity $\sim 34.0 \mathrm{psu})$ and high sea surface temperatures $\left(\sim 30^{\circ} \mathrm{C}\right)$ characteristic of the Philippines relative to other nurseries (Antonov et al. 2010, Gordon et al. 2011) may be responsible for the 0.13 to $1.27 \%$ depletion in $\delta^{13} \mathrm{C}_{\text {otolith }}$ of YOY yellowfin tuna collected from this nursery. Additionally, Chen et al.

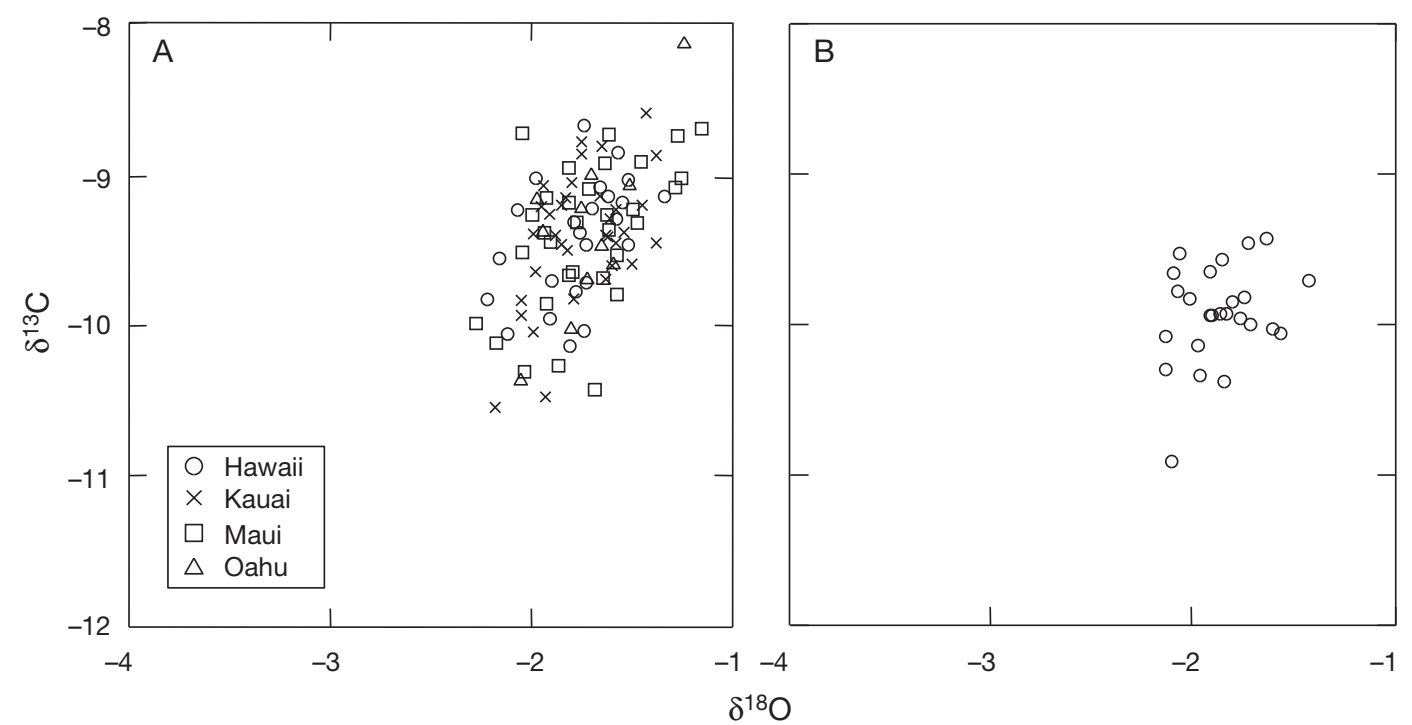

Fig. 4. Thunnus albacares. Otolith core carbon $\left(\delta^{13} \mathrm{C}_{\text {otolith }}\right)$ and oxygen $\left(\delta^{18} \mathrm{O}_{\text {otolith }}\right)$ stable isotopes of sub-adult (age-1) yellowfin tuna collected (A) among different islands (Hawaii, Kauai, Maui, Oahu) within the nearshore Hawaiian Islands and (B) offshore Hawaiian Islands 


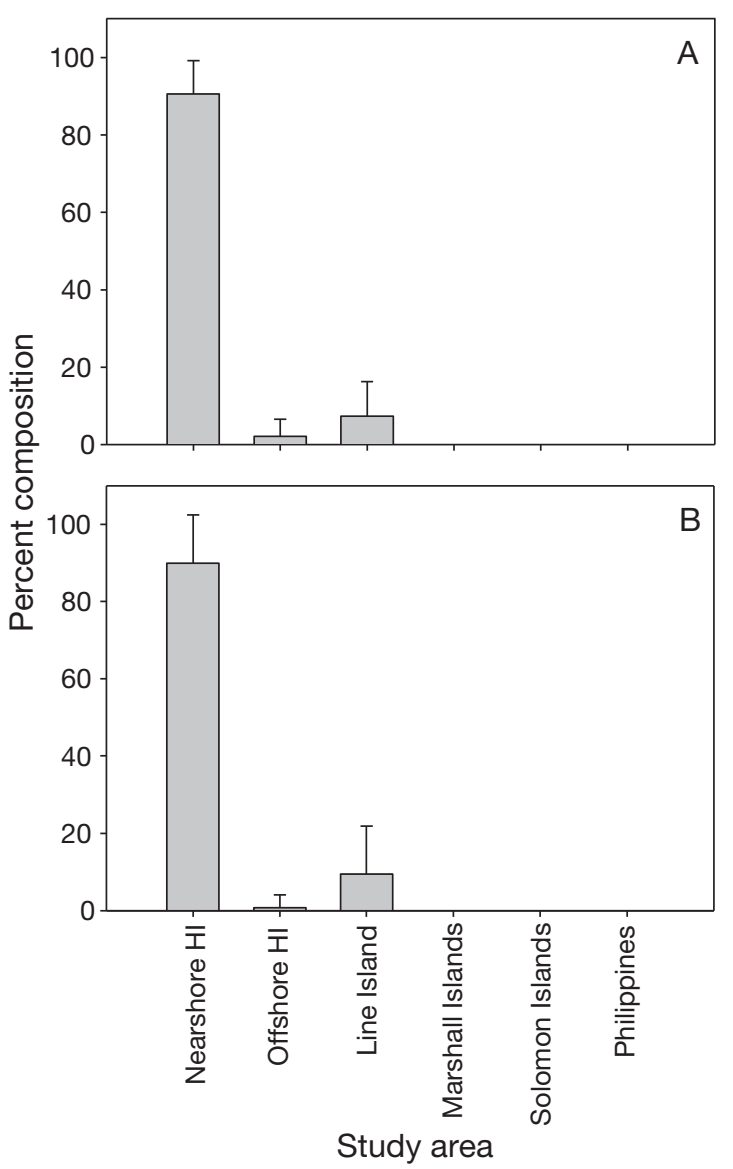

Fig. 5. Thunnus albacares. Nursery origin contribution estimates (mean + SD percent composition) of sub-adult (age-1) yellowfin tuna collected at the (A) nearshore Hawaiian Islands (HI) and (B) offshore Hawaiian Islands. Results were derived from mixed-stock analysis using baseline samples collected in 2008

(2006) reported similar patterns of low seawater $\delta^{13} \mathrm{C}$ $\left(\delta^{13} \mathrm{C}_{\text {seawater }}\right)$ in the western Pacific with an increasing trend in $\delta^{13} \mathrm{C}_{\text {seawater }}$ from west to east along the tropical and sub-tropical North Pacific and linked this relationship to the zonal pattern of $\mathrm{CO}_{2}$ solubility in surface waters. The enriched $\delta^{13} \mathrm{C}_{\text {otolith }}$ of YOY yellowfin tuna collected in the Marshall Islands cannot be explained by the aforementioned salinity and temperature patterns alone since the Hawaiian Island nurseries have highest salinity and lowest sea surface temperatures that would lead to expected

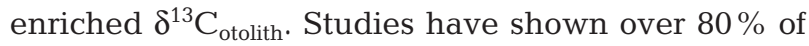
$\delta^{13} \mathrm{C}_{\text {otolith }}$ is derived from food and dissolved inorganic carbon (DIC) of ambient seawater (Solomon et al. 2006) and therefore the isotopic composition of the basal carbon sources and prey species specific to the Marshall Islands may account for the enriched $\delta^{13} \mathrm{C}_{\text {otolith }}$ of YOY yellowfin tuna in this nursery. $\delta^{18} \mathrm{O}_{\text {otolith }}$ of YOY yellowfin tuna match spatial trends to seawater $\delta^{18} \mathrm{O}\left(\delta^{18} \mathrm{O}_{\text {seawater }}\right)$ and salinity patterns reported for the WCPO. A decreasing trend in surface $\delta^{18} \mathrm{O}_{\text {seawater }}$ (upper $50 \mathrm{~m}$ ) from the central $(0.4 \%$, $n=72$ observations) to western equatorial Pacific Ocean $(0.1 \%$, $\mathrm{n}=122)$ reported by Schmidt et al. (1999) matched the pattern of decreasing $\delta^{18} \mathrm{O}_{\text {otolith }}$ from central to western nurseries examined. Mean $\delta^{18} \mathrm{O}_{\text {otolith }}$ differences between the Line Islands (central) and Philippines (western) nurseries were 0.55 and $0.58 \%$ in 2008 and 2009, respectively, slightly larger than the $0.30 \%$ o difference in $\delta^{18} \mathrm{O}_{\text {seawater. In the }}$ WCPO, sea surface salinity and $\delta^{18} \mathrm{O}_{\text {seawater }}$ are positively correlated, and both are affected by evaporation, precipitation, and atmospheric convection (Stott et al. 2004). $\delta^{18} \mathrm{O}_{\text {otolith }}$ is a function of evaporation (increases ${ }^{18} \mathrm{O}$ in seawater) and precipitation (decreases ${ }^{18} \mathrm{O}$ in seawater). It is also positively correlated with sea surface salinity (Campana 1999), often increasing by 0.2 (Kerr et al. 2007) to $1.4 \%$ o (Dufour et al. 1998) per 1 psu increase. The warm, low-salinity surface waters (mean salinity: $\sim 34.0 \mathrm{psu}$ ) of the western equatorial Pacific contrasts the cool and more saline surface waters of the central equatorial Pacific (Line Islands, salinity: $234.5 \mathrm{psu}$ ) (Schmidt et al. 1999, Antonov et al. 2010) and matched the 0.5 to $0.6 \%$ odifference in $\delta^{18} \mathrm{O}_{\text {otolith }}$ from central and western equatorial nurseries. Similar trends of decreasing $\delta^{18} \mathrm{O}_{\text {seawater }}$ and $\delta^{18} \mathrm{O}_{\text {otolith }}$ were observed north to south with nearshore Hawaiian Islands $\delta^{18} \mathrm{O}_{\text {seawater }}$ enriched by $0.04 \%$ relative to the southerly located Line Islands nursery at a similar longitude (Schmidt et al. 1999). Moreover, mean $\delta^{18} \mathrm{O}_{\text {otolith }}$ was enriched by $0.3 \%$ in 2008 and $0.6 \%$ in 2009 at the nearshore Hawaiian Islands (relative to the Line Islands) where mean salinity averages approximately 35.0 psu (Schmidt et al. 1999, Antonov et al. 2010), about 0.5 to $1.0 \mathrm{psu}$ higher than other nurseries examined.

Inter-annual variability in $\delta^{13} \mathrm{C}_{\text {otolith }}$ and $\delta^{18} \mathrm{O}_{\text {otolith }}$ was minimal among the nurseries investigated, except the Philippines, which may have resulted from variability in climactic and oceanographic conditions. Samples collected from the Philippines nursery showed differences in both $\delta^{13} \mathrm{C}_{\text {otolith }}$ and $\delta^{18} \mathrm{O}_{\text {otolith }}$ during the 2 yr study and may be related to the El Niño Southern Oscillation (ENSO), which affected precipitation, sea surface salinity, and sea surface temperatures in our Philippines nursery. Late 2007 (August to December) and early 2008 (January to April) was a moderately strong La Niña period (Climate Prediction Center 2010), and this time period coincides with the spawning season of our 2008 YOY samples with depleted $\delta^{13} C_{\text {otolith }}$ and 
enriched $\delta^{18} \mathrm{O}_{\text {otolith }}$ compared to 2009 samples collected the following year (late 2008 to early 2009). La Niña events generally produce heavy precipitation and cyclone activity in the western Pacific (Ropelewski \& Halpert 1996); however, a seasonal reversal of the ENSO rainfall is unique to the Philippines area during summers of La Niña periods resulting in below average rainfall (Lyon et al. 2006). The seasonal southwest monsoon that usually produces high precipitation was significantly weakened resulting in fewer tropical cyclones, thereby blocking the northward migration of the inter-tropical convergence zone (Yumul et al. 2010). Consequently, anomalously low precipitation and high evaporation led to higher salinities in late 2007 to early 2008 (mean salinity: $34.1 \mathrm{psu}$ ) compared with late 2008 to early 2009 (mean salinity: 33.6 psu) (Gordon et al. 2011). Our 2007 to 2008 YOY Philippine samples had lower $\delta^{13} \mathrm{C}_{\text {otolith }}$ relative to the 2008 to 2009 samples despite being exposed to lower precipitation and higher salinities that would lead to increased $\delta^{13} \mathrm{C}_{\text {otolith }}$. However, mean sea surface temperature in late 2007 to early 2008 was $2^{\circ} \mathrm{C}$ higher than in 2008 to 2009 (Gordon et al. 2011), which may have contributed to the $0.69 \%$ lower $\delta^{13} \mathrm{C}_{\text {otolith }}$ in 2007 to 2008 based on the previously reported inverse relationships between $\delta^{13} \mathrm{C}_{\text {otolith }}$ and sea surface temperature (Elsdon \& Gillanders 2002). A direct comparison of $\delta^{13} \mathrm{C}_{\text {otolith }}$ with ambient seawater conditions may be difficult since otolith $\delta^{13} \mathrm{C}$ is also a product of diet, metabolism, and kinetic effects (Høie et al. 2003). With respect to $\delta^{18} \mathrm{O}_{\text {otolith, }}$ several studies have used $\delta^{18} \mathrm{O}_{\text {otolith }}$ in coral skeleton to assess inter-annual changes in sea surface salinity during ENSO events in the western Pacific and found years with decreased precipitation (and high evaporation) resulted in higher salinities and enriched $\delta^{18} \mathrm{O}_{\text {seawater }}$ and coral skeleton $\left(\delta^{18} \mathrm{O}_{\text {coral }}\right)$ (Morimoto et al. 2002, Iijima et al. 2005). Specifically, changes in sea surface salinity of approximately 0.5 resulted in a corresponding $\delta^{18} \mathrm{O}$ change of approximately half $(0.25 \%)$ in $\delta^{18} \mathrm{O}_{\text {seawater }}$ and $\delta^{18} \mathrm{O}_{\text {coral }}$. Salinity differences between years in the Philippines averaged 0.5 (Gordon et al. 2011) and thus the $\delta^{18} \mathrm{O}_{\text {otolith }}$ difference of $0.2 \%$ was between published models using $\delta^{18} \mathrm{O}_{\text {otolith }}$ values predicting $0.1 \%$ (Kerr et al. 2007) and $\delta^{18} \mathrm{O}_{\text {coral }}$ of $0.3 \%$ (Morimoto et al. 2002) per 0.5 psu difference.

Estimates of nursery origin using $\delta^{13} \mathrm{C}_{\text {otolith }}$ and $\delta^{18} \mathrm{O}_{\text {otolith }}$ for sub-adult yellowfin tuna collected in the nearshore Hawaiian Islands indicate these individuals were primarily derived from local production. Our estimate of over $90 \%$ of sub-adults collected in the nearshore Hawaiian Islands from the same nearshore nursery suggests that retention is high and movement of YOY yellowfin tuna away from these waters may be limited. The hypothesis of local retention or limited movement of yellowfin tuna in the Hawaiian Islands is supported by recent tagging studies. Adam et al. (2003) reported that a large percentage (97\%) of yellowfin tuna tagged in the nearshore Hawaiian Islands were later recaptured in the same region, and previous work by Itano \& Holland (2000) documented that displacement distances of YOY and subadult yellowfin tuna throughout the Hawaii exclusive economic zone (EEZ) was typically under $50 \mathrm{~km}$ with individuals remaining within this zone. In addition, tracks derived from archival tagged yellowfin tuna in the main Hawaiian Islands have shown localized movements around a single island or from one island to another with no significant displacements away from the main island group (K. Holland unpubl. data). Several studies have suggested that localized and restricted movement of these fish may be linked to the quality and quantity of available habitat, primarily natural bathymetric features (reef ledges, seamounts) and fish aggregation devices (FADs) (Holland et al. 1990, Brill et al. 1999, Itano \& Holland 2000, Dagorn et al. 2007). In addition, prey availability found in the nearshore waters of the Hawaiian Islands is enriched by a diverse land-associated mesopelagic boundary community of vertically migrating nekton located close to the main Hawaiian Islands, supporting the expectation that these waters serve as productive foraging areas for YOY and subadult yellowfin tuna (Reid et al. 1991, Brock 1985). Although otolith chemistry and tagging results support the premise of local production and retention in the nearshore waters of Hawaii, both also indicate the potential for low levels of exchange with nurseries to the south. Otolith chemistry data indicated that sub-adult yellowfin tuna collected in the nearshore Hawaiian Islands had minor contribution estimates from the 2 closest nurseries to the south (offshore Hawaiian Islands, Line Islands), which is not unexpected given that limited exchange has been reported between the nearshore Hawaiian Islands and these regions (Adam et al. 2003). All potential nurseries for yellowfin tuna throughout the WCPO were not sampled for baselines; however, spatial coverage of nurseries sampled likely provided sufficient resolution of $\delta^{13} \mathrm{C}_{\text {otolith }}$ and $\delta^{18} \mathrm{O}_{\text {otolith }}$ patterns needed for estimating contribution estimates.

Enriched $\delta^{18} \mathrm{O}_{\text {otolith }}$ values in otolith cores of the subadult yellowfin tuna sampled from the offshore Hawaiian Island nursery closely matched the YOY nearshore Hawaiian Islands baseline, suggesting that 
a large fraction ( $90 \%$ ) of the sub-adults obtained from the offshore Hawaiian Islands originated from the nearshore Hawaiian Islands. While the majority of yellowfin tuna tagged in nearshore waters of the Hawaiian Islands have shown restricted movement, some individuals were recaptured outside of the main Hawaiian Islands farther south (ca. 200 to $500 \mathrm{~km}$ ) from tagging locations (Itano \& Holland 2000, D. G. Itano unpubl. data). Nearshore to offshore movement of yellowfin tuna in the Hawaiian Islands has been documented with fish tagged near the nearshore Hawaiian Islands later recaptured south at the Cross Seamount (offshore Hawaiian Island nursery) (Adam et al. 2003). Sibert et al. (2000) reported that migrants to the Cross Seamount were largely derived from other unknown source(s), with these individuals moving to other locations in the WCPO after frequenting this location for relatively short periods of time. Our findings clearly show that an important source of recruits to the Cross Seamount is the nearshore Hawaiian Islands, and therefore the population dynamics of sub-adult yellowfin at the Cross Seamount will be dependent to some degree on local production in the nearshore waters of Hawaii.

This study highlights the importance of nearshore waters of the Hawaiian Islands as critical nurseries of yellowfin tuna and indicates that this nursery is the primary source of sub-adult yellowfin tuna in both nearshore and offshore waters of Hawaii. Our results suggest that the contribution of equatorial nurseries to Hawaii's domestic fisheries may be more limited $(<10 \%)$ than previously assumed, but show that a south to north immigration route occurs for yellowfin tuna, which until now has only been supported by a single long distance tag recovery (Secretariat of the Pacific Community unpubl. data). Relative contribution rates of recruits from local and more distant nurseries to the south of the Hawaiian Islands may experience strong inter-annual variability and because our research was based on a single year class of sub-adults, additional research is warranted to determine whether local production and retention of yellowfin tuna in the Hawaiian Islands varies significantly across cohorts.

Acknowledgements. Funding for this work was provided by the University of Hawai'i Pelagic Fisheries Research Program (JIMAR project 651106 to J.R.R. and D.G.I.). R.J.D.W. was supported in part by a Texas Institute of Oceanography postdoctoral research fellowship. We thank the numerous individuals for assistance in otolith collections, including G. Castrence, P. Conley, J. Dettling, B. Fukuda, D. Fuller, E-J Kim, K. Lind, J. Muir, B. Muller, K. Pollock, K. Schaefer, S. Tobiason, and T. Usu. Special thanks to R. Schloesser for assistance processing otolith samples.

\section{LITERATURE CITED}

Adam MS, Sibert J, Itano DG, Holland KN (2003) Dynamics of bigeye (Thunnus obesus) and yellowfin (T. albacares) tuna in Hawaii's pelagic fisheries: analysis of tagging data with a bulk transfer model incorporating sizespecific attrition. Fish Bull 101:215-228

Antonov JI, Seidov D, Boyer TP, Locarnini RA and others (2010) World ocean atlas 2009, Vol 2: Salinity. In: Levitus $\mathrm{S}$ (ed) NOAA Atlas NESDIS 69. US Government Printing Office, Washington, DC

Brill RW, Block BA, Boggs CH, Bigelow KA, Freund EV, Marcinek DJ (1999) Horizontal movements and depth distribution of large adult yellowfin tuna (Thunnus albacares) near the Hawaiian Islands, recorded using ultrasonic telemetry: implications for the physiological ecology of pelagic fishes. Mar Biol 133:395-408

Brock RE (1985) Preliminary study of the feeding habits of pelagic fish around Hawaiian fish aggregation devices or can fish aggregation devices enhance local fisheries productivity? Bull Mar Sci 37:40-49

Campana SE (1999) Chemistry and composition of fish otoliths: pathways, mechanisms and applications. Mar Ecol Prog Ser 188:263-297

> Chen M, Guo L, Ma Q, Qiu Y, Zhang R, Lv E, Huang Y (2006) Zonal patterns of $\delta^{13} \mathrm{C}, \delta^{15} \mathrm{~N}$, and ${ }^{210} \mathrm{Po}$ in the tropical and subtropical North Pacific. Geophys Res Lett 33: L04609 doi:10.1029/2005GL025186

Climate Prediction Center (2010) El Niño Southern Oscillation diagnostic discussion-monthly climate diagnostic bulletin. National Center for Environmental Prediction. www.ncep.noaa.gov

> Dagorn L, Holland KN, Itano DG (2007) Behavior of yellowfin (Thunnus albacares) and bigeye (T. obesus) tuna in a network of fish aggregating devices (FADs). Mar Biol 151:595-606

> Díaz-Jaimes P, Uribe-Alcocer M (2006) Spatial differentiation in the eastern Pacific yellowfin tuna revealed by microsatellite variation. Fish Sci 72:590-596

> Dufour V, Pierre C, Rancher J (1998) Stable isotopes in fish otoliths discriminate between lagoonal and oceanic residents of Taiaro Atoll (Tuamotu Archipelago, French Polynesia). Coral Reefs 17:23-28

Elsdon TS, Gillanders BM (2002) Interactive effects of temperature and salinity on otolith chemistry: challenges for determining environmental histories of fish. Can J Fish Aquat Sci 59:1796-1808

> Gordon AL, Sprintall J, Ffield A (2011) Regional oceanography of the Philippine Archipelago. Oceanography 24: $14-27$

Gunn JS, Ward RD (1994) The discrimination of yellowfin tuna sub-populations within the AFZ. Phase 1: a pilot study to determine the extent of genetic and otolith microchemical variability in populations from different parts of the Pacific and Indian Oceans. Final report to Fisheries Research and Development Corporation (FRDC 91/27). CSIRO Division of Fisheries, Hobart

> Hampton J, Fournier DA (2001) A spatially disaggregated, length-based, age-structured population model of yellowfin tuna (Thunnus albacares) in the western and central Pacific Ocean. Mar Freshw Res 52:937-963

> Høie H, Folkvord A, Otterlei E (2003) Effect of somatic and otolith growth rate on stable isotope composition of early juvenile cod (Gadus morhua L) otoliths. J Exp Mar Biol Ecol 289:41-58 
Holland KN, Brill RW, Chang RKC (1990) Horizontal and vertical movements of yellowfin and bigeye tuna associated with fish aggregating devices. Fish Bull 88:493-507

Iijima H, Kayanne H, Morimoto M, Abe O (2005) Interannual sea surface salinity changes in the western Pacific from 1954 to 2000 based on coral isotope analysis. Geophys Res Lett 32:L04608 doi:10.1029/2004GL022026

Itano DG (2000) The reproductive biology of yellowfin tuna (Thunnus albacares) in Hawaiian waters and the western tropical Pacific Ocean: project summary. SOEST Publ0001, JIMAR Contribution 00-328, JIMAR, Honolulu, HI

Itano DG, Holland KN (2000) Movement and vulnerability of bigeye (Thunnus obesus) and yellowfin tuna (Thunnus albacares) in relation to FADs and natural aggregation points. Aquat Living Resour 13:213-223

Kerr LA, Secor DH, Kraus RT (2007) Stable isotope $\left(\delta^{13} \mathrm{C}\right.$ and $\delta^{18} \mathrm{O}$ ) and $\mathrm{Sr} / \mathrm{Ca}$ composition of otoliths as proxies for environmental salinity experienced by an estuarine fish. Mar Ecol Prog Ser 349:245-253

Langley A, Hoyle S, Hampton J (2011) Stock assessment of yellowfin tuna in the western and central Pacific Ocean. Scientific Committee Seventh Regular Session, Pohnpei, Federated States of Micronesia, 9-17 August 2011. WCPFC-SC7-2011/SA WP-03. Western and Central Pacific Fisheries Commission, Kolonia

Lehodey P, Leroy B (1999) Age and growth of yellowfin tuna (Thunnus albacares) from the western and central Pacific Ocean as indicated by daily growth increments and tagging data. Standing Committee on Tuna and Billfish 12, working paper YFT-2. Ocean Fisheries Programme, Secretariat of the Pacific Community, Noumea

Lyon B, Cristi H, Verceles ER, Hilario FD, Abastillas R (2006) Seasonal reversal of the ENSO rainfall signal in the Philippines. Geophys Res Lett 33:L24710 doi:10.1029/ 2006GL028182

McGarigal K, Cushman S, Stafford S (2000) Multivariate statistics for wildlife and ecology research. Springer-Verlag, New York, NY

Millar RB (1990) Comparison of methods for estimating mixed stock fishery composition. Can J Fish Aquat Sci 47:2235-2241

Morimoto M, Abe O, Kayanne H, Kurita N, Matsumoto E, Yoshida N (2002) Salinity records for the 1997-98 El Niño from western Pacific corals. Geophys Res Lett 29: 1540 doi:10.1029/2001GL013521

> Reid SB, Hirota J, Young RE, Hallacher LE (1991) Mesopelagic-boundary community in Hawaii: micronekton at the interface between neritic and oceanic ecosystems. Mar Biol 109:427-440

Rooker JR, Secor DH, Zdanowicz VS, Itoh T (2001) Discrimination of northern bluefin tuna from nursery areas in the Pacific Ocean using otolith chemistry. Mar Ecol Prog Ser 218:275-282

Rooker JR, Secor DH, De Metrio G, Kaufman AJ, Belmonte Rios A, Ticina V (2008a) Evidence of trans-Atlantic movement and natal homing of bluefin tuna from stable isotopes in otoliths. Mar Ecol Prog Ser 368:231-239

Rooker JR, Secor DH, De Metrio G, Schloesser R, Block BA, Neilson JD (2008b) Natal homing and connectivity in Atlantic bluefin tuna populations. Science 322:742-744

Ropelewski CF, Halpert MS (1996) Quantifying Southern Oscillation-precipitation relationships. J Clim 9: 1043-1059

Schaefer KM (1992) An evaluation of geographic and annual variation in morphometric characters and gill-raker counts of yellowfin tuna, Thunnus albacares, from the Pacific Ocean. Bull I-ATTC 20:133-163

Schaefer KM, Fuller DW, Block BA (2007) Movements, behavior, and habitat utilization of yellowfin tuna (Thunnus albacares) in the northeastern Pacific Ocean, ascertained through archival tag data. Mar Biol 152:503-525

Schloesser RW, Neilson JD, Secor DH, Rooker JR (2010) Natal origin of Atlantic bluefin tuna (Thunnus thynnus) from Canadian waters based on otolith $\delta^{13} \mathrm{C}$ and $\delta^{18} \mathrm{O}$. Can J Fish Aquat Sci 67:563-569

Schmidt GA, Biggs GR, Rohling EJ (1999) Global seawater oxygen-18 database, version 1.21. NASA Goddard Institute for Space Studies. Accessed on 05/15/2012. data.giss.nasa.gov/o18data/

Shiao JC, Yui TF, Høie H, Ninnemann U, Chang SK (2009) Otolith $\mathrm{O}$ and $\mathrm{C}$ stable isotope compositions of southern bluefin tuna Thunnus maccoyii (Pisces: Scombridae) as possible environmental and physiological indicators. Zool Stud 48:71-82

Shiao JC, Wang SW, Yokawa K, Ichinokawa M, Takeuchi Y, Chen YG, Shen CC (2010) Natal origin of Pacific bluefin tuna Thunnus orientalis inferred from otolith oxygen isotope composition. Mar Ecol Prog Ser 420:207-219

Sibert J, Holland KN, Itano DG (2000) Exchange rates of yellowfin and bigeye tunas and fishery interaction between Cross Seamount and near-shore FADs in Hawaii. Aquat Living Resour 13:225-232

Solomon CT, Weber PK, Cech JJ Jr, Ingram BL, Conrad ME, Machavaram MV, Pogodina AR, Franklin RL (2006) Experimental determination of the sources of otolith carbon and associated isotopic fractionation. Can J Fish Aquat Sci 63:79-89

Stott L, Cannariato K, Thunell R, Haug GH, Koutavas A, Lund S (2004) Decline of surface temperature and salinity in the western tropical Pacific Ocean in the Holocene epoch. Nature 431:56-59

Uchiyama JH, Struhsaker P (1981) Age and growth of skipjack tuna, Katsuwonus pelamis, and yellowfin tuna, Thunnus albacares, as indicated by daily growth increments of sagittae. Fish Bull 79:151-162

Wang CH, Lin YT, Shiao JC, You CF, Tzeng WN (2009) Spatio-temporal variation in the elemental compositions of otoliths of southern bluefin tuna Thunnus maccoyii in the Indian Ocean and its ecological implication. J Fish Biol 75:1173-1193

Ward RD, Elliot NG, Innes BH, Smolenski AJ, Grewe PM (1997) Global population structure of yellowfin tuna, Thunnus albacares, inferred from allozyme and mitochondrial DNA variation. Fish Bull 95:566-575

Wild A (1986) Growth of yellowfin tuna, Thunnus albacares, in the eastern Pacific Ocean based on otolith increments. Bull I-ATTC 18:423-482

Williams P, Terawasi P (2011) Overview of tuna fisheries in the western and central Pacific Ocean, including economic conditions - 2010. Scientific Committee, 7th Regular Session, Pohnpei, Federated States of Micronesia, 9-17 August 2011. WCPFC-SC7-2011/GN WP-1. Western and Central Pacific Fisheries Commission, Kolonia

> Yumul GP, Cruz NA, Dimalanta CB, Servando NT, Hilario FD (2010) The 2007 dry spell in Luzon (Philippines): its cause, impact and corresponding response measures. Clim Change 100:633-644

Submitted: January 4, 2012; Accepted: May 22, 2012

Proofs received from author(s): July 20, 2012 